\title{
Screening of Lactic Acid Bacteria from Effluent Samples of Jaipur Dairy Neha Sharma ${ }^{1 *}$, Neetu Yadav², Harshita Bhagwani², Darshan Chahar ${ }^{2}$ and Bhumesh Singh ${ }^{3}$
}

${ }^{1}$ Department of Zoology and Convener- Research \& Development, Poddar International College, Jaipur, Rajasthan, India

${ }^{2}$ Environmental Microbiology and Toxicology, Poddar International College, Jaipur, Rajasthan, India

${ }^{3}$ UNESCO Category 2 Centre, Wildlife Institute of India, Uttarakhand, India

\begin{abstract}
Probiotics are good or friendly bacteria that are essential for good health. Probiotic literally means "for life" as opposed to antibiotic meaning "against life." Probiotics are single-celled lactic bacteria organisms occurring primarily singly or in pairs. Probiotics are live microbial food supplements or components of bacteria, which have been shown to have beneficial effects on human health. The most commonly used probiotic strains belong to genera Lactobacillus $s p .$, Bifidobacterium and Saccharomyces sp. taking into consideration, the above cited facts, and the present study was conducted to isolate and characterise probiotic strains from dairy waste water. Untreated and treated dairy waste water samples were collected from Jaipur dairy in accordance with standard procedures. Morphological and biochemical tests were conducted to identify the strains. The most common and predominant isolate was found to be associated with genera Leuconostoc sp.
\end{abstract}

Keywords: Dairy waste water; Jaipur dairy; Lactobacillus; Microbial feed supplements; Probiotics

\section{Introduction}

Agro-industrial residues are the most abundant and renewable resources on earth. Biomass accumulation in large quantities every year results not only in the deterioration of the environment, but it also causes loss of potentially valuable material which could be processed and converted into various different value-added products [1].

Dairy industry produces huge volumes of waste, both in solid and liquid forms. This waste aggravates disposal and pollution problems due to high biological oxygen demand (BOD) or chemical oxygen demand (COD) values and represents a loss of valuable biomass and nutrients. Despite of hazard aspects, in many cases dairy processing wastes have a good potential of getting converted into useful products of higher value as by- product, or even as raw material for other industries, thereby employing best out of waste strategy. Such wastes could be utilized as cheap sources of micro-organisms to produce intermediate volume of high value organic acids like lactic acid [2]. Lactic Acid is one such product which has found phenomenal importance in different industrial sectors as a preservative and acidifying agent in food and dairy industry; a monomer for biodegradable polylactic acid polymers (PLA) in the textile, medical and packaging industries; precursor and chemical feedstock for chemical, textile and leather industries $[3,4]$. Moreover, production of lactate esters (e.g. butyl lactate) is another growing application as environmentally friendly solvents [5]. In Indian scenario, the annual production capacity of lactic acid is reported to be 6000 tones and as a prediction, the estimated supply gap of 2300tones by 2015 needs to be furnished [6]. Current employability of lactic acid in multiple facets is represented in Figure 1.

Wastes generated from dairy plants may be regarded as a viable option for meeting this growing demand for lactic acid, if appropriate biotechnological interventions are used. The plausible role of indigenous microbes and that too Lactic Acid Bacteria (LAB) has been substantiated in near past. Lactic acid bacteria (LAB) are a heterogeneous group of Gram-positive bacteria consisting twelve different genera viz., Lactobacillus, Lactococcus, Leuconostoc, Oenococcus, Pediococcus, Streptococcus, Tetragenococcus, Aerococcus Carnobacterium Enterococcus, Vagococcus and Weissella [7].
They are non sporulating rods or cocci which produce lactic acid as the main fermentation product under suitable substrates. LAB ferment sugars via homo-, hetero-, or mixed acid fermentation. Homofermentative LAB produces lactic acid as main product from sugars, while hetero- or mixed acid fermentations produce also ethanol and/or acetic acid, formic acid and carbon dioxide. Their use as dairy starter cultures has become an industry during this century where they are mainly associated with manufacturing of fermented dairy products such as cheese, dahi, yoghurt, buttermilk, sour cream [8]. Dairy wastes can wastes can be exploited as inexpensive sources of new probiotic strains of LAB to produce value added products [7].

\section{Materials and Methods}

\section{Sample collection}

Dairy effluent samples were collected from Effluent treatment Plant of Jaipur dairy [9]. The samples were aseptically collected in presterilized bottles and stored on ice until transported to the laboratory. The samples were refrigerated at $4^{\circ} \mathrm{C}$ and analysed within $24 \mathrm{~h}$ of collection. The samples were indicated as IDWW (Inlet Dairy Waste Water) and ODWW (Outlet Dairy Waste Water) (Figures 2 and 3).

\section{Isolation of lactic acid bacteria from dairy effluents}

Effluent samples were serially diluted in $0.1 \%$ sterile peptone water. Different dilutions were quadrant streaked on MRS agar (de Man, Rogosa and Sharpe) media with the following composition (Tables 1 and 2).

*Corresponding author: Neha Sharma, Senior Assistant Professor, Head Department of Zoology and Convener- Research \& Development, Poddar International College, Sector-7, Shipra Path, Mansarovar, Jaipur-302020, Rajasthan, India, Tel: +917597783062; E-mail: nehamicrobiologist@gmail.com

Received March 28, 2018; Accepted April 16, 2018; Published April 23, 2018

Citation: Sharma N, Yadav N, Bhagwani H, Chahar D, Singh B (2018) Screening of Lactic Acid Bacteria from Effluent Samples of Jaipur Dairy. Int J Waste Resour 8: 332. doi: 10.4172/2252-5211.1000332

Copyright: $\odot 2018$ Sharma N, et al. This is an open-access article distributed unde the terms of the Creative Commons Attribution License, which permits unrestricted use, distribution, and reproduction in any medium, provided the original author and source are credited. 
Citation: Sharma N, Yadav N, Bhagwani H, Chahar D, Singh B (2018) Screening of Lactic Acid Bacteria from Effluent Samples of Jaipur Dairy. Int J Waste Resour 8: 332. doi: 10.4172/2252-5211.1000332

Page 2 of 4

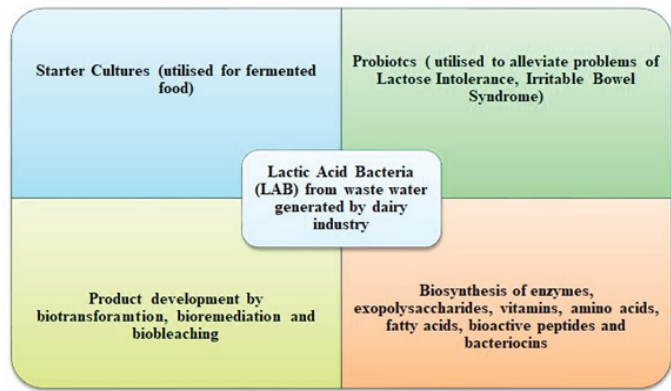

Figure 1: Commercial applications of lactic acid bacteria (lab) in different industrial processing sections.

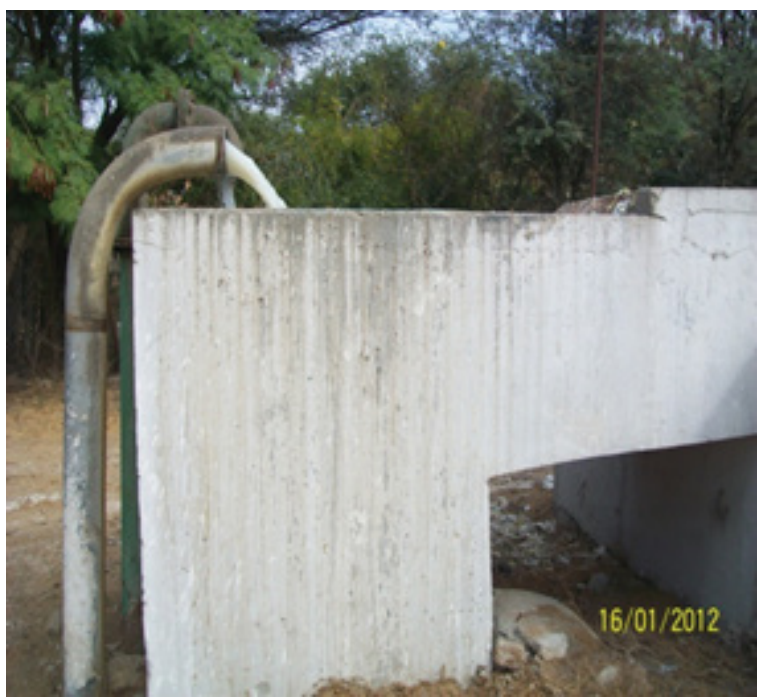

Figure 2: IDWW (inlet dairy waste water).

\section{Confirmation tests of LAB}

Morphological and biochemical characterisation of screened isolates was carried out in accordance with standard procedures using culture dependent approach [10]. Different tests like gram staining, catalase, oxidase, sugar fermentation (arabinose, lactose, maltose, sucrose, ribose, rhamnose, mannitol and sorbitol), starch, lipid hydrolysis, oxygen requirement, and motility.

\section{Evaluation of probiotic properties}

Growth at different temperatures and $\mathrm{NaCl}$ concentrations: This experiment was conducted in accordance with the protocol devised [11]. Briefly, $5 \mathrm{ml}$ of test MRS broth supplemented with bromo cresol purple indicator at a concentration of $0.12 \mathrm{~g} / \mathrm{l}$ was dispensed into tubes. $0.1 \mathrm{ml}$ of actively grown cultures inoculated into tubes at incubated for 4-6 days at varying temperatures at 4,37 and $45^{\circ} \mathrm{C}$. Qualitative colour change from purple to yellow was observed during incubation period. Likewise, the isolates were tested for tolerance to different $\mathrm{NaCl}$ concentrations $(4 \%$ and $6.5 \% \mathrm{NaCl})$. The procedure of incubation was similar.

Resistance to low pH: The most important feature of probiotic properties is resistance to low $\mathrm{pH}$. Overnight grown strains were sub cultured into $2 \mathrm{ml}$ of fresh MRS broth and incubated for another $24 \mathrm{~h}$

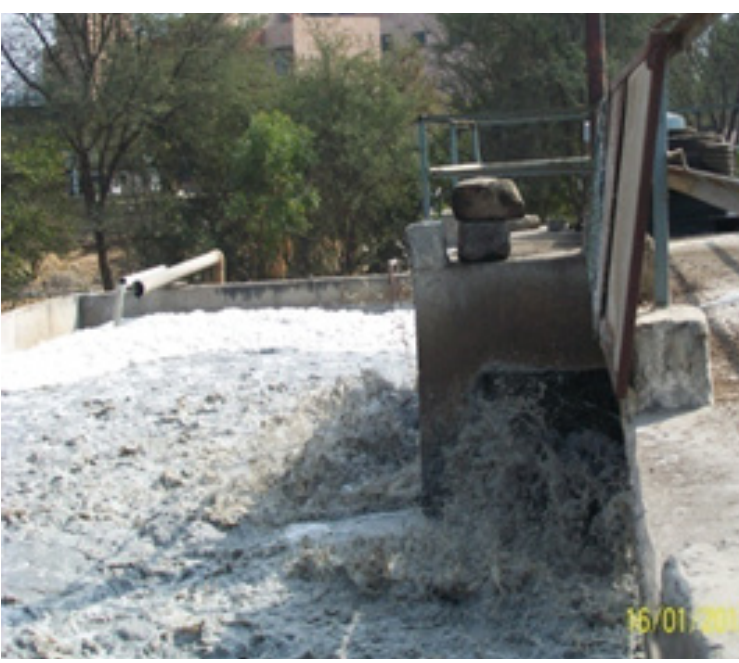

Figure 3: ODWW (outlet dairy waste water).

\begin{tabular}{|c|c|c|}
\hline S.No & Contents & $\mathbf{W} / \mathbf{v}$ \\
\hline 1 & Peptone & $1 \%$ \\
\hline 2 & Beef Extract & $1 \%$ \\
\hline 3 & Yeast Extract & $1 \%$ \\
\hline 4 & Glucose & $2 \%$ \\
\hline 5 & Sodium acetate trihydrate & $0.5 \%$ \\
\hline 6 & Polysorbate 80 & $0.1 \%$ \\
\hline 7 & Dipotassium hydrogen phosphate & $0.2 \%$ \\
\hline 8 & Triammonium citrate & $0.2 \%$ \\
\hline 9 & Magnesium sulphate heptahydrate & $0.02 \%$ \\
\hline 10 & Mangnese sulfate tetrahydrate & $0.05 \%$ \\
\hline 11 & Agar & $1 \%$ \\
\hline
\end{tabular}

Table 1: Composition of MRS media for isolation of $L A B$.

\begin{tabular}{|c|c|c|}
\hline S.No & Contents & w/v \\
\hline 1 & Peptone & $1 \%$ \\
\hline 2 & Beef Extract & $1 \%$ \\
\hline 3 & Yeast Extract & $1 \%$ \\
\hline 4 & Glucose & $2 \%$ \\
\hline 5 & Sodium acetate trihydrate & $0.5 \%$ \\
\hline 6 & Polysorbate 80 & $0.1 \%$ \\
\hline 7 & Dipotassium hydrogen phosphate & $0.2 \%$ \\
\hline 8 & Triammonium citrate & $0.2 \%$ \\
\hline 9 & Magnesium sulphate heptahydrate & $0.02 \%$ \\
\hline 10 & Mangnese sulfate tetrahydrate & $0.05 \%$ \\
\hline 11 & Sodium Azide & $0.02 \%$ \\
\hline 12 & Sucrose & $0.02 \%$ \\
\hline 13 & Bromo-cresol purple & $0.012 \%$ \\
\hline 11 & Agar & $1 \%$ \\
\hline
\end{tabular}

Table 2: Composition of modified MRS media for isolation of LAB.

to reach the late exponential phase. The culture was then centrifuged at $8000 \mathrm{rpm}$ for $10 \mathrm{~min}$ at $4^{\circ} \mathrm{C}$ and pellet was re suspended in $2 \mathrm{ml}$ of MRS broth previously adjusted with $\mathrm{HCl}$ to a final $\mathrm{pH}$ value of 3 . The culture was incubated at $37^{\circ} \mathrm{C}$ for up to $24 \mathrm{~h}$. Samples were withdrawn at regular intervals of $0,1,2,3$ and $24 \mathrm{~h}$ from the onset of incubation to determine the survivability. $0.1 \mathrm{ml}$ aliquot of the culture and its 10 fold serial dilutions were plated on MRS agar medium. Plates were 
incubated at $37^{\circ} \mathrm{C}$ for $48 \mathrm{~h}$ and the $\mathrm{LAB}$ counts were expressed in colony forming units per milliliter $(\mathrm{cfu} / \mathrm{ml})$. A positive control consisting of regular MRS broth inoculated with the culture was simultaneously set up.

\section{Results and Discussion}

\section{Isolation and characterization of lactic acid bacteria from dairy effluents}

Many white to cream colonies were readily observed on MRS agar plates within less than $24 \mathrm{~h}$ at $37^{\circ} \mathrm{C}$. Colonies from MRS plates streaked onto modified MRS were unable to grow thereby confirming that the bacterium was a non-LAB. Bromocresol purple, which is a $\mathrm{pH}$ indicator that changes colour from purple around neutral $\mathrm{pH}$ to yellow below $\mathrm{pH}$ 5. It is a differential agent that allows discrimination of LAB from nonLAB [12]. Modified MRS agar also contains sodium azide, a selective agent, since it is a potent iron porphyrin inhibitor and is effective in inhibiting the growth of most non LAB and fungi on the modified MRS plates. Growth of LAB is not inhibited in the presence of sodium azide [12].

\section{Confirmation tests of the LAB isolate}

Genera of rod shaped LAB include Lactobacillus, Bifidobacterium, Corynebacterium, Bacillus and Sporolactobacillus while common coccus shaped LAB include Lactococcus, Streptococcus, Enterococcus and Pediococcus. Morphologically, leuconostocs generally appear as cocci similar in size and shape to lactococci (Table 3), however, some Leuconostocs tend to have a coccoid or coccobacillary morphology due to cell elongation [13]. In lieu of the microscopic investigation, the isolate presumably belonged to genera Leuconostoc sp (Figure 4). Catalase is an enzyme produced by many microorganisms that breaks down hydrogen peroxide into water and oxygen and causes gas bubble formation [8]. Given that Leuconostoc cells are catalase negative coccobacilli often associated with milk and dairy products [14].

With respect to incubation test in phenol red glucose broth, the isolate was found to produce gas at the top of the inverted Durham tube with a colour change from red to yellow. These observations indicate that the isolate is heterofermentative. i.e., is able to ferment glucose to produce $\mathrm{D}(-)$ lactic acid, ethanol and $\mathrm{CO}_{2}$ Most leuconostocs are fermentative and are able to produce $\mathrm{CO}_{2}$ from glucose. Benmechernene $\mathrm{Z}$ [15] showed that all 83 strains of $L$. mesenteroides isolated from 12

\begin{tabular}{|c|c|c|}
\hline S.No & Characteristic & Appearance \\
\hline 1 & Colony shape & Circular \\
\hline 2 & Colony colour & Yellowish -orange \\
\hline 3 & Colony pattern & Convex \\
\hline 4 & Colony margin & Entire \\
\hline 5 & Gram stain & Positive \\
\hline 6 & Cell shape & Negative \\
\hline 7 & Catalase & Positive \\
\hline 8 & Glucose & Positive \\
\hline 9 & Sucrose & Negative \\
\hline 10 & Arabinose & Negative \\
\hline 11 & Rhamnose & Positive \\
\hline 12 & Maltose & Negative \\
\hline 13 & Rhamnose & Negative \\
\hline 14 & Ribose & Negative \\
\hline 15 & Mannitol & Positive \\
\hline 16 & Lactose & ine \\
\hline
\end{tabular}

Table 3: Isolation and characterization of lactic acid bacteria from dairy effluents.

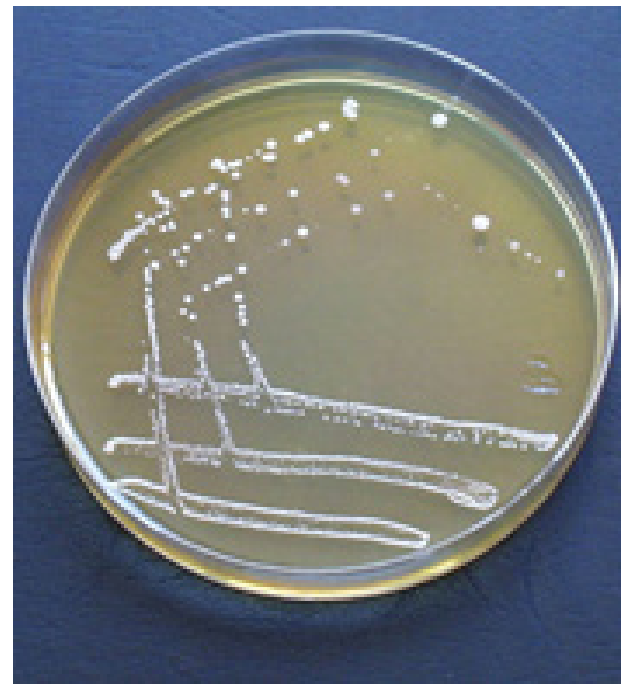

Figure 4: Pure culture of Leuconostoc $s p$. isolated from dairy effluent.

raw camel milk samples were able to produce carbon dioxide from glucose. The term "fermentation" is often used to describe the catalytic activity of a carbohydrate under anaerobic conditions. Bacteria capable of fermenting a carbohydrate are usually referred to as facultative anaerobes [16]. Different bacteria catabolize different energy sources in the medium depending on the specific enzymes synthesized. Most bacteria possess the enzyme systems required for the oxidation and utilization of the simple sugar, glucose.

\section{Growth characteristics of the isolate}

Another criterion for the evaluation of the probiotic trait of the isolate is the ability to grow at different temperatures. Our findings revealed that the isolate could not grow at $4^{\circ} \mathrm{C}$ or $45^{\circ} \mathrm{C}$ over the 7 day incubation period although it was able to grow at $37^{\circ} \mathrm{C}$. Our findings were in harmony with [16] Leuconostoc strains isolated from raw camel milk were also classified as mesophiles as they were able to grow at 30 and $37^{\circ} \mathrm{C}$ but not at 4 and $45^{\circ} \mathrm{C}$. Azadnia $\mathrm{P}$ [17] also reported that Leuconostoc mesenteroides was able to grow at $4 \% \mathrm{NaCl}$ concentration but not at $6.5 \% \mathrm{NaCl}$ concentration.

\section{Resistance to low $\mathrm{pH}$ and bile salts}

With respect to its acid tolerance, the isolate was found to survive in $\mathrm{pH}$ of 3.0 for $>24 \mathrm{~h}$ at $37^{\circ} \mathrm{C}$. Although there was a decrease in the population by ca. $3.6 \log \mathrm{cfu} / \mathrm{ml}$ over the first 3 hours of exposure to high acidity, a surviving population of $>5 \log \mathrm{cfu} / \mathrm{ml}$ was observed. Resistance to low $\mathrm{pH}$ is one of the major selection criteria for probiotic strains [18]. Before reaching the intestinal tract, probiotic bacteria must first survive the acidity of the stomach [19]. Hence, the $\mathrm{pH}$ of the in vitro assay was adjusted to mimic the gastric $\mathrm{pH}$. Since the bulk luminal $\mathrm{pH}$ of the stomach typically ranges from 1 to 3 , a $\mathrm{pH}$ value of 3.0 was chosen since there is a significant decrease in the viability of strains at $\mathrm{pH} 2.0$ or lower [11]. The exposure times to low $\mathrm{pH}$ were set for 1, 3, 4 and $24 \mathrm{~h}$ since the average residence time of food in the stomach is ca. 3 hours but can vary widely from person to person, either naturally or due to several factors. The population of the isolate declined rapidly by $3.6 \log \mathrm{cfu} / \mathrm{ml}$ over the first 3 hours.

Similarly, Grosu-Tudor SS [20] observed high survival rates of Leuconostoc citreum 344 and Leuonostoc mesenteroides 348 of the 
order of $10^{8} \mathrm{cfu} / \mathrm{ml}$, following a 3 fold exposure at $\mathrm{pH} 3$. After $24 \mathrm{~h}$ of incubation at $\mathrm{pH} 3.0$ however, the viability decreased to $10^{4} \mathrm{CFU} /$ $\mathrm{ml}$. The usual tolerance of probiotic strains to low $\mathrm{pH}$ can be attributed to the physico- chemical characteristics of the source where they are isolated. Probiotic LAB isolated from dairy samples typically ferment milk sugar lactose into lactic acid. During acidification of milk, the $\mathrm{pH}$ decreases from 6.7 to 4.6 . Therefore, it can be presumed that the $\mathrm{pH}$ of the dairy effluents is $\leq 4.6$ [21]. Hence, it is possible that the isolate of this study was the dominating species in the dairy effluents, reflecting a possible adaptation to the specific environment [20]. Since probiotic LAB is known to exhibit high tolerance to bile in the human GI tract, the isolate was incubated in the presence of $0.3 \%$ bile salts for $4 \mathrm{~h}$ in an in vitro bile assay to simulate conditions of the human gastro intestinal tract.

\section{Conclusion}

A lactic acid bacterium was isolated from dairy effluents of Effluent Treatment Plant (ETP) of Jaipur Dairy. To ascertain its probiotic potential, the isolate was subjected to different biochemical physiological, biochemical and viability tests. The isolate was found to be a catalase negative, hetero fermentative, gram positive cocco bacillus that was able to ferment glucose as well as disaccharides such as lactose, sucrose and maltose. The isolate was tolerant to low $\mathrm{pH}(\mathrm{pH}=3)$, presence of bile salts $(0.3 \%)$ as well as moderate concentrations of $\mathrm{NaCl}$ (4\%). Furthermore, the studies are in progress in our laboratory to establish the bio-efficacy potential to produce lactic acid at pilot scale.

\section{References}

1. Taurisano V, Anzlemo G, Poli A, Nicolaus B, Donato PD (2014) Re-use of Agroindustrial waste: Recovery of valuable compounds by eco-friendly techniques. Int J Performability Engg 10: 419-425.

2. Nihir SN, Patel A (2013) Lactic acid bacteria in the treatment of dairy waste and formation of by-products-a promising approach. Ind Food Indus Mag 32: 45-49.

3. Taskila S, Ojamo H (2013) The current status and future expectations in industrial production of lactic acid by lactic acid bacteria. InTech Open, pp: 616632.

4. Dukic-Vukovic AJ, Mojovic LV, Vukasinovic Sekulic M, Rakin M, Nikolic S (2011) New trends and challenges in lactic acid production on renewable biomass. Chem Ind 65: 411-422.
5. Wee YJ Kim JN, Ryu HW (2006) Biotechnological production of lactic acid and its recent applications. Food Technol Biotechnol 44: 163-172.

6. Ashe B, Paul S (2010) Isolation and characterization of $L A B$ from dairy effluents J Environ Res Develop 4: 983-991.

7. Hudaa N, Boubadoor N, Sanmukhiya MR (2015) Isolation, characterisation and determination of probiotic properties of Lactic Acid Bacteria from effluents of dairy plant in Mauritius. Int J Biol Pharm and Allied Sci 4: 320-333.

8. Kim ER, Cho YH, Park SO, Woo GJ, Chun HN (2010) Comparison of bifidobacteria selective media for the detection of Bifidobacteria in Korean commercial fermented milk products. Kor J of Food Sci and Ani Res 30: 154162

9. https://www.mwa.co.th/download/file_upload/SMWW_1000-3000.pdf

10. Cappucino JG, Shermann N (2009) Microbiology: A Laboratory Manual. Pearson Education. Benjamin Cummings, San Francisco.

11. Yavuzdurmaz H (2007) Isolation, characterization and determination of probiotic properties of lactic acid bacteria from human milk. Izmir Institute of Technology, Turkey.

12. Sobrun Y, Bhaw AL, Jhury D, Puchooa D (2012) Isolation of lactic acid bacteria from sugar cane juice and production of lactic acid from selected improved strains. Adv Bios and Biotechnol 3: 398- 407.

13. Lonvaud AF, Batt C, Tortorello ML (1999) Leuconostocaceae family, Encyclopedia of Food Microbiology. Academic Press, London. pp: 455-465.

14. Nikita C, Hemangi D (2012) Isolation, identification and characterization of lactic acid bacteria from dairy sludge sample. J Environ Res Dev 7: 234-244.

15. Benmechernene Z, Chentouf HF, Yahia B, Ghazi F, Quintela MB, et al. (2013) Technological aptitude and applications of Leuconostoc mesentroides bioactive strains isolated from algerian raw camel milk. BioMed Res Inter 32: 418132.

16. http://www.asmscience.org/content/education/protocol/protocol.3779

17. Azadnia P, Khan AH (2009) Identification of lactic acid bacteria isolated from traditional drinking yoghurt in tribes of Fars province. Iran J Vet Res 10: 28-33.

18. Soda ME, Ahmed N, Omran G, Osman A, Morsi S (2003) Isolation, identification and selection of Lactic Acid Bacteria cultures for cheese making. Emi J Agri Sci 15: $51-71$

19. Harish K, Varghese T (2006) Probiotics in humans -evidence based review Cali Med J 4: 3-6

20. Grosu-Tudor SS, Zamfir M (2012) Probiotic potential of some Lactic Acid Bacteria isolated from romanian fermented vegetables. Ann Rom Soc Cell Biol 17: 234-230.

21. Lee WJ, Lucey JA (2010) Formation and physical properties of yogurt. Asian Aust J Ani Sci 23: 1127-1136. 